\title{
Sexual solicitation of Latino male day laborers by other men
}

\author{
Frank H Galvan, PhD, ${ }^{(I)}$ Daniel J Ortiz, PhD, ${ }^{(I)}$ Victor Martínez, BS, (2) Eric G Bing, MD, PhD. ${ }^{(I)}$
}

\section{Galvan FH, Ortiz DJ, Martínez V, Bing EG. Sexual solicitation of Latino male day laborers by other men. Salud Publica Mex 2008;50:439-446.}

Galvan FH, Ortiz DJ, Martínez V, Bing EG.

Solicitación sexual de hombres

jornaleros latinos por otros hombres

Salud Publica Mex 2008;50:439-446.

\begin{abstract}
Objective. To examine the likelihood of Latino day laborers being solicited for sex by other men. Material and Methods. 450 Latino day laborers were recruited in Los Angeles, California, from July to September 2005. Logistic regression analysis was used to determine which day laborers were more likely to be solicited and subsequently to have sex. Results. Thirty-eight percent reported being solicited for sex by another man while seeking work. Those solicited were more likely to live longer in the US, be more educated and screen positive for drug dependence. Of those solicited, $9.4 \%$ had sex with their solicitors. Those screening positive for drug dependence were more likely to have sex. Most of the day laborers who had anal sex with their solicitors did not always use condoms. Conclusions. HIV prevention efforts should target drug dependent day laborers, who may place themselves at risk for HIV through sex with male solicitors.
\end{abstract}

Key words: HIV; migrants; sexual behavior; homosexuality, male; employment; Los Angeles

\section{Resumen}

Objetivo. Examinar hasta qué punto los jornaleros latinos son solicitados por otros hombres para tener relaciones sexuales. Material y métodos. Cuatrocientos cincuenta jornaleros latinos fueron reclutados en Los Ángeles, California, de julio a septiembre de 2005. Un análisis de regresión logística fue utilizado para determinar cuáles jornaleros tenían más probabilidades de que fueran solicitados $y$, subsecuentemente, de que tuvieran sexo. Resultados. Treinta y ocho por ciento reportaron que fueron solicitados para sexo por otros hombres mientras buscaban trabajo. Estos hombres que fueron solicitados tenían más probabilidades de haber vivido más tiempo en los Estados Unidos, tener más educación formal y dar resultados positivos en dependencia de drogas. De los solicitados, 9.4\% tuvieron sexo con los solicitadores. Aquellos que dieron resultados positivos para dependencia de drogas tenían más probabilidades de tener sexo. La mayoría de los jornaleros que tuvieron sexo anal con los solicitadores no siempre usaron condón. Conclusiones. Esfuerzos de prevención delVIH deben dirigirse a jornaleros dependientes de drogas quienes pueden estar exponiéndose al riesgo de contraer $\mathrm{VIH}$ al tener sexo con solicitadores masculinos.

Palabras clave: $\mathrm{VIH}$; migrantes; conducta sexual; homosexualidad masculina; empleo; Los Ángeles

(I) Institute for Community Health Research, Charles Drew University of Medicine and Science. Los Angeles, CA, USA.

(2) Bienestar Human Services, Inc. Los Angeles, CA, USA.

Received on: February 15, 2008 - Accepted on: June 25, 2008 Address reprint requests to: Frank H. Galvan. PhD. Institute for Community Health Research, Charles Drew University of Medicine and Science. I73I East I20 th Street. Los Angeles, CA 90059, USA

E-mail: frankgalvan@cdrewu.edu 
A number of factors are associated with the risk of HIV infection among Latino migrant workers in the United States. These include engaging in sexual activities with commercial sex workers, having many sex partners, sharing needles after the injection of illegal drugs or substances taken for "therapeutic" reasons and abusing alcohol and drugs. ${ }^{1}$ Compounding such risk factors are a number of other issues, such as disruptions in family lives, poverty, low levels of formal education and literacy rates, limited English proficiency and undocumented residency status. ${ }^{1}$

The limited literature that exists on HIV and Latino migrant men has focused primarily on migrants living in rural areas or small cities who are usually or primarily farm workers ${ }^{2-4}$ or on those described solely as "migrant laborers." ${ }^{5-6}$ Limited information is available on the HIVrelated risk behaviors of day laborers, the overwhelming majority of whom are Latino immigrants. ${ }^{7}$

It is estimated that there are approximately 117600 day laborers on any given day in the United States either looking for day labor jobs or employed as day laborers. ${ }^{7}$ Day workers seek jobs primarily through informal locations, such as standing in front of businesses, home improvement stores, gas stations and on busy streets; only one in five seeks work at an official day laborers work center. $^{7}$

Ethnographic studies conducted with Latino day laborers reveal that most day laborers report coming to the U.S. to support their families in their countries of origin. ${ }^{8-9}$ Many borrowed money from friends or relatives to cover transit costs and as a result may spend their first few months after arrival repaying their debts. Many are homeless or share housing with other men in order to save on housing costs. Often their primary attention and focus is on earning enough money to send home to their families and for this reason many hardships are endured. ${ }^{8}$

Valenzuela et al. ${ }^{7}$ found that most day laborers $(83 \%)$ rely on their day labor work as their only source of income. Most are at or below the federal poverty level. Valenzuela et al. also found rampant violations of day laborers' rights, including not being paid for their work, working under hazardous conditions and being subject to insults from employers.

One study that focused exclusively on the HIV-related risk behaviors of Latino day laborers was conducted by Organista \& Kubo. ${ }^{10}$ They interviewed 102 workers in Northern California. They reported that knowledge of proper condom use was generally low among the men interviewed. However, higher condom use was reported by men who had multiple female sexual partners compared to those with only one sexual partner. None of the men in the study reported any sexual activities with other males during the previous two months.
The limited information available on Latino day laborers' risk of HIV infection leaves other questions unanswered. For example, to what extent are day laborers solicited for sex by other men while they seek employment? Ehrlich et al. ${ }^{11}$ asked their sample of 290 male Latino migrant day laborers if they had ever heard of men being offered money for sex at day labor sites. Seventy-five percent reported that they had heard of men offering day laborers money for sex at work sites. However, Ehrlich et al. did not ask the day laborers if they themselves had been approached for sex at day labor sites, nor what their responses had been. Such solicitations could potentially place them at risk of HIV infection, especially if some day laborers feel compelled for economic reasons to accept the sexual solicitations from these men, even if this involves high-risk sexual activities. Thus, there is a need to obtain more information about the extent to which Latino day laborers may be at risk for HIV infection through the sexual solicitations from other men while seeking day labor employment.

In addition, information is now available on the Internet for men interested in meeting Latino day laborers for sexual activities. This includes the locations of specific day labor sites in different cities in the United States, along with the names of street corners or business establishments where day laborers congregate. Also included are specific details of how to target Latino day laborers for sexual activities, tips on how to approach them, suggested payment amounts, best times of the day to make contact and detailed graphic stories of sexual encounters with day laborers.

This study had two specific aims: (1) to determine the extent to which male Latino day laborers are solicited for sex by other men while seeking work at specific day labor sites, and (2) to determine the extent to which day laborers engage in sex with their male solicitors and the factors associated with such behavior. This information can suggest possible directions in the creation of HIV prevention programs that respond more specifically to the needs of male Latino day laborers and contribute to lowering the risk of HIV infection for themselves and their partners.

\section{Material and Methods}

\section{Procedures and participants}

Six day labor sites were chosen in the city of Los Angeles, California in the USA. The location of five of these sites was obtained from information on the Internet about where to find Latino day laborers for potential sexual encounters. The other site was located near one of these other sites and was identified by day laborers themselves, and so it was included as well. 
A convenience sample of 450 Latino day laborers was recruited for the study from July to September 2005. Of these, all were recruited from sites mentioned on the Internet except for 10 individuals recruited from the nearby site mentioned above. Participants were between the ages of 18 to 40 years of age. This particular age group was targeted on the assumption that individuals soliciting day laborers for sex would be more inclined to approach younger, rather than older men. Individuals who appeared to meet the age criteria were approached by a Latino male research interviewer. The interviewer introduced himself and stated that he was interviewing Latino day laborers for a study examining the extent to which Latino day laborers between the ages of 18 to 40 years of age are at risk for HIV. The individual was asked if he was between those ages. If the person indicated that he was, the interviewer then informed him that if he volunteered for the study he would be asked questions about sexual behaviors, drug use and alcohol use. He was informed that the interview would last between 30 to 45 minutes and that he would receive $\$ 15$ for his participation.

Those interested in participating were then asked to walk to a nearby private location and administered a questionnaire after providing informed consent (which included information that a Certificate of Confidentiality had been obtained from the National Institutes of Health and thereby providing an additional safeguard of confidentiality to the participants). Upon reading the consent form, the individuals were also informed that they would be asked questions about whether they had ever been approached for sex while seeking work as a day laborer. This information was not initially provided at the screening stage when the men were first approached about the study because of the concern that other day laborers at the day labor site could make the assumption that the individuals agreeing to participate in the study had in fact been solicited for sex while seeking work. All of the interviews were conducted in Spanish.

\section{Measures}

Each participant provided information on his age, country of birth, years lived in the U.S., years of education, years working as a day laborer, relationship status (married, not married but living with a partner, or single), sexual orientation, previous year's income, residency status in the U.S., history of ever having tested for HIV and HIV serostatus. Harmful drinking was assessed through the Alcohol Use Disorders Identification Test (AUDIT). ${ }^{12-13}$ The AUDIT is a 10-item screener which includes three questions on the frequency and quantity of alcohol con- sumption as well as three questions on alcohol dependence and four questions on problem drinking during the previous year. Scores of 8 or higher indicate a strong likelihood of harmful alcohol consumption.

Drug dependence was assessed using the Texas Christian University Drug Screen II (TCUDS II). ${ }^{14}$ Questions were asked about the use of various drugs during the previous 12 months (the category of alcohol was excluded from the TCUDS since it was covered by the AUDIT). Values of 3 or greater indicate relatively severe drug-related problems and correspond approximately to a drug dependence diagnosis. Participants testing positive for either the alcohol or drug screeners were provided with appropriate referrals for follow-up substance abuse care as necessary. "Sex with men in the previous 12 months" was assessed based on an affirmative response to reporting having given or received oral or anal sex with another man.

Participants were also asked the following question: "During the time that you have been a day laborer in California, has a man propositioned you for sex while you were seeking work or after you had been hired to work?" If an individual responded in the affirmative to this question, he was then asked a series of other questions. These questions inquired about the number of times that they had been propositioned, how often they had engaged in sex after being propositioned (always, usually, sometimes and never), how often payment for sex had been involved, the reasons for having accepted payment, the types of sexual activities that had been involved (active or passive oral sex and active or passive anal sex) and how often a condom had been used in these occasions (always, usually, sometimes or never).

\section{Analysis}

Descriptive statistics were obtained on all the study variables. In addition, bivariate and multivariate logistic regressions were used to determine the association of independent variables with the likelihoods of being approached for sex and also of having sex after being solicited by another man. The multivariate models included the variables that were significant at the bivariate level at $p \leq 0.25$ following the recommendations of Hosmer \& Lemeshow. ${ }^{15}$ Variables that were correlated with others were omitted from the final multivariate models: the choice between these variables was determined by the strength of their association with the outcome variables at the bivariate level. Due to space limitations, the results of the bivariate models are not reported. All tests were conducted using Stata 6.0 (College Station, TX: Stata Corporation, 1999). 


\section{Results}

\section{Sample characteristics}

The sample characteristics are presented in table I. The day laborers were fairly equally divided among the three age categories. Nearly half of the sample was born in Mexico. Nearly three-quarters had been in the United States for five years or less. Most had only six years of education or less. The mean number of years of educa- tion for the sample was 6.7 years. Sixty percent were single and a quarter married. Of those who were married, the vast majority $(81 \%$; $\mathrm{n}=92)$ reported that their spouse did not live with them in the United States.

Ninety percent reported having worked as a day laborer for five years or less. The mean number of years reported working as a day laborer was 2.61 (this number was subsequently used as the cutoff for the bivariate and multivariate analyses). Almost four-fifths reported the previous year's income as having been $\$ 8000$ or less.

Table I

\section{Sample characteristics, Los Angeles, California, USA. July to September 2005}

\begin{tabular}{lcc} 
Variables & $N$ & Percent* \\
Total & 450 & 100.0 \\
Age in years & & \\
$\quad>18 \&<23$ & 140 & 31.1 \\
\hline$\geq 24 \& \leq 31$ & 149 & 33.1 \\
\hline$\geq 32 \& \leq 40$ & 161 & 35.8 \\
& & \\
Country of birth & & \\
Mexico & 221 & 49.1 \\
\hline Guatemala & 158 & 35.1 \\
\hline El Salvador & 33 & 7.3 \\
\hline Honduras & 28 & 6.2 \\
\hline Other Central American country & 4 & 0.9 \\
\hline South American country & 4 & 0.9 \\
\hline Cuba & I & 0.2 \\
\hline United States & I & 0.2
\end{tabular}

Variables

N Percent*

Years worked as a day laborer

\begin{tabular}{lrr}
$\leq 1$ & 187 & 41.6 \\
\hline$>1 \& \leq 5$ & 218 & 48.4 \\
\hline$>5$ & 45 & 10.0
\end{tabular}

Previous year's income

\begin{tabular}{lrr}
$\leq \$ 4,000$ & 173 & 38.4 \\
\hline$>\$ 4,000 \& \leq \$ 8,000$ & 182 & 40.4 \\
\hline$>\$ 8,000 \& \leq \$ 12,000$ & 64 & 14.2 \\
\hline$>\$ 12,000 \& \leq \$ 29,000$ & 31 & 6.9
\end{tabular}

Residency status in U.S.

\begin{tabular}{lrr} 
U.S. citizen & 4 & 0.9 \\
\hline Legal resident & 18 & 4.0 \\
\hline Undocumented worker & 399 & 88.7 \\
\hline Other ${ }^{\ddagger}$ & 29 & 6.4
\end{tabular}

Years lived in the U.S.

\begin{tabular}{lrr}
$\leq 1$ & 126 & 28.0 \\
\hline$>1 \& \leq 5$ & 209 & 46.4 \\
\hline$>5 \& \leq 10$ & 81 & 18.0 \\
\hline$>10$ & 34 & 7.6
\end{tabular}

History of HIV testing

\begin{tabular}{lll} 
Yes & 228 & 50.7 \\
\hline No & 222 & 49.3
\end{tabular}

\begin{tabular}{lll}
$\begin{array}{l}\text { Harmful drinking } \\
\text { Yes }\end{array}$ & 196 & 43.6 \\
\hline No & 254 & 56.4
\end{tabular}

\begin{tabular}{lrr}
$\leq 6$ & 265 & 58.9 \\
\hline$>6 \& \leq 12$ & 172 & 38.2 \\
\hline$>12$ & 13 & 2.9
\end{tabular}

Drug dependence

\begin{tabular}{rrr} 
Yes & 75 & 16.7 \\
\hline No & 375 & 83.3
\end{tabular}

Relationship status

\begin{tabular}{lrr} 
Single & 271 & 60.2 \\
\hline Not married but living with a partner & 66 & 14.7 \\
\hline Married & 113 & 25.1
\end{tabular}

* The percentages do not always add to $100 \%$ because of rounding

‡ Visa (student, worker or tourist) $=25$, immigration paperwork in process $=3$, asylum $=$ । 
The mean previous year's income for the sample was $\$ 6040$. Almost 90\% described their residency status as being undocumented. Half reported having ever been tested for HIV, and only one person reported being HIV-positive.

Forty-four percent met the criteria for harmful drinking. Seventeen percent reported having relatively severe drug-related problems which corresponded approximately to drug dependence. Among these individuals, the drugs causing the most serious problems were cocaine or crack (35\%), marijuana (35\%), methamphetamines $(25 \%)$, tranquilizers or sedatives $(3 \%)$, and inhalants (1\%).

Almost the entire sample $(98.4 \% ; \mathrm{n}=443)$ described their sexual orientation as being heterosexual. Slightly over $1 \%(\mathrm{n}=6)$ reported being bisexual, and one person described his orientation as "other." No one reported being exclusively homosexual or gay. Eighty-four percent $(n=378)$ reported having been sexually active in the previous 12 months.

\section{Sexual solicitations of day laborers}

One hundred and seventy one (38\%) of the day laborers reported having been propositioned for sex by another man while they were seeking work or after they had been hired to work. Of those who reported having been approached, $21.6 \%$ reported that this had occurred once, 22.8\% twice, $19.9 \% 3$ times, $5.8 \% 4$ times, $9.4 \% 5$ times and $20.5 \% 6$ or more times, with a range of from 1 time to 100 times.

Of those who reported having been approached, the overwhelming majority $(90.6 \%)(n=155)$ reported never having engaged in sex with the individuals who approached them. The remaining $9.4 \%(n=16)$ reported having had sex with their solicitors. Of those who had sex after being propositioned, five reported that they always engaged in sex with their solicitors, five usually and six sometimes. Of the 16 men, 12 of them described themselves as heterosexual, three as bisexual and one as "other." Fourteen reported having received a payment for their sexual activities from their solicitors at least sometimes. All of these 14 individuals reported that they accepted the payment because they needed the money, and 12 of the individuals who were paid reported that it was also because they had not had any work that particular day they had been solicited. Among the 14 who received payment, two men also responded that they had done so because they themselves were "homosexual or bisexual." Only 4 of the 14 men who had been paid by their solicitors gave as a reason that they liked to have sex with other men, and 10 stated that that was not a reason for doing so.
Among the 16 individuals who did have sex, 14 reported having had penetrative anal sex. Of these, four reported always using a condom, four only sometimes, and six never. Only one person reported having had receptive anal sex, adding that he used a condom only sometimes.

\section{Characteristics of day laborers who are solicited and also those who accept solicitations}

Table II shows the results of multivariate analyses used to determine the association of different independent variables with the likelihood of being solicited and the likelihood of having sex after being solicited. The latter model includes only those men who reported having been approached for sex by other men $(n=171)$.

A greater likelihood for being solicited was found for those who had lived in the U.S. for over 10 years (compared to those with one year or less), those with more than six years of education and those who met the criteria for drug dependence. A greater likelihood for having sex after being solicited was found only for those who were drug dependent.

\section{Discussion}

\section{Sexual solicitation of day laborers}

Nearly $40 \%$ of the day laborers interviewed reported having been propositioned for sex by another man while they were seeking work or after they had been hired to work. Over half of those who reported having been approached stated that it had occurred three or more times. Thus the day labor sites where the study took place had a large number of day laborers who reported having been solicited for sex by other men while they were seeking work.

Despite the large number who report having been approached for sex by other men while looking for day labor employment, only a very small percent, less than $10 \%$, ended up having sex with their solicitors. The overwhelming majority of those who reported having been approached by other men reported never having engaged in sex with the individuals who approached them.

\section{Reasons for having sex with a solicitor}

For the $88 \%$ who received financial compensation for their sexual activities, all of them reported having done so because they needed the money and $86 \%$ of these also stated that it was because they had not had any work that particular day that they had been solicited for sex. 
Table II

SeXual solicitations of day laborers (MUltivariate logistic Regressions*),

Los Angeles, California, USA. July to September 2005

\begin{tabular}{|c|c|c|c|}
\hline \multirow[b]{2}{*}{ Variables } & \multicolumn{2}{|c|}{$\begin{array}{l}\text { Likelihood of being solicited } \\
\qquad n=450\end{array}$} & $\begin{array}{l}\text { Likelihood of accepting solicitation } \\
\qquad n=171\end{array}$ \\
\hline & AOR & $95 \%$ C & $95 \% \mathrm{Cl}$ \\
\hline
\end{tabular}

Age in years

\begin{tabular}{lrr}
$\geq 18 \& \leq 23$ & 1.00 & - \\
\hline$\geq 24 \& \leq 31$ & 1.75 & $0.29-10.8$ \\
\hline$\geq 32 \& \leq 40$ & 3.00 & $0.53-17.1$
\end{tabular}

Years lived in the U.S.

\begin{tabular}{lll}
$\leq 1$ & 1.00 & - \\
\hline$>1 \& \leq 5$ & 1.33 & $0.81-2.19$ \\
\hline$>5 \& \leq 10$ & 1.49 & $0.79-2.80$ \\
\hline$>10$ & $2.63^{\ddagger}$ & $1.11-6.27$
\end{tabular}

Years of education

\begin{tabular}{cccccc}
$\leq 6$ & 1.00 & - & 1.00 & - & 0.09 \\
\hline$>6$ & $1.58^{\ddagger}$ & $1.06-2.37$ & $0.33^{\&}$ & 0.1 .15
\end{tabular}

Relationship status

\begin{tabular}{lllll} 
Single & 1.00 & - & 1.00 & - \\
\hline Not married but living with a partner & 1.37 & $0.78-2.44$ & 1.39 & $0.29-6.66$ \\
\hline Married & 0.88 & $0.55-1.42$ & $3.29^{\&}$ & $0.90-12.1$
\end{tabular}

Residency status in U.S.

\begin{tabular}{llc} 
Undocumented worker & 1.00 & - \\
\hline All others & 0.99 & $0.50-1.93$
\end{tabular}

History of HIV testing

\begin{tabular}{ccc} 
No & 1.00 & - \\
\hline Yes & 1.24 & $0.82-1.87$
\end{tabular}

Drug dependence

$\begin{array}{llllll}\text { No } & 1.00 & - & 1.00 & - & 1.76-17.7\end{array}$

* Multivariate models include only those variables that were significant at the bivariate level at $p \leq 0.25$ and exclude those factors that were correlated with other variables in the models

$\ddagger p \leq 0.05$

$\S p \leq 0.01$

$\# p \leq 0.001$

\& $p \leq 0.10$

The importance of financial need as a reason for having sex with a solicitor is further substantiated by the fact that 10 of the 14 men who reported having been paid for sex by their solicitors stated that enjoying sex with another man was not a reason for having sex for pay.
Thus economic need appears to play a significant role in agreeing to have sex with a solicitor.

Nevertheless, it is possible that, for some day laborers, being solicited by other men provided them with an opportunity to have sex with another man, despite 
the fact that most of the men who engaged in sex with their solicitors described themselves as heterosexual. Further research, especially qualitative in-depth interviews, could provide additional insight into why some day laborers have sex with their solicitors.

\section{Characteristics of the sexual activities reported}

The vast majority of the day laborers who did have sex had anal sex (primarily penetrative but also receptive). Few reported using condoms always. In addition, 88\% reported having received payment for their sexual activities from their solicitors. It is clear that both the day laborers who are participating in these activities and their sexual partners may be placing themselves at risk for HIV by engaging in anal sex without condoms.

\section{Factors associated with being solicited and with having sex with a solicitor}

More years of living in the U.S. and of education as well as meeting the criteria for drug dependence were found to be associated with a greater likelihood of reporting having been solicited. It is possible that individuals with longer residencies in the U.S. and higher levels of education may also have a greater proficiency with English and hence a greater ability to understand when potential employers are soliciting sex. It is also possible that the solicitors themselves may be more willing to solicit individuals who demonstrate better use of English, as would be expected among individuals with longer periods of time living in the U.S. Further examination is warranted into the factors that contribute to the choice of who is approached for sexual solicitation.

Screening positive for drug dependence was found to be associated both with a greater likelihood of reporting having been solicited and also with a greater likelihood of having sex with a solicitor. It is possible that drug dependent individuals may be placing themselves in situations that result in being solicited for sexual activity and subsequently engaging in it. One explanation for this may be that drug dependent men may see having sex with other men as an opportunity to make money in order to pay for their drug-taking habits. Our findings are consistent with research with similar populations that has found using illegal drugs to be associated with sexual risk behaviors associated with HIV transmission. ${ }^{2}$

\section{Limitations}

Since day laborers were not randomly selected, we are not able to generalize beyond the individuals interviewed in this study. In addition, given the pilot nature of the study, we limited the study to day labor sites where we knew from the Internet that solicitation of day laborers was occurring and one other site in close proximity. Because we did not survey sites not identified on the Internet or not located in close geographical proximity to such sites, we are not able to compare the information obtained from the sites chosen for this study to other meeting places of day laborers. Thus we do not know the extent to which similar sexual solicitations of day laborers may be occurring at other day labor sites.

Another limitation relates to the measurement of the dependent variables of being solicited for sex by men and accepting those solicitations. Given that migrants similar to those of this study have provided low self-reports of sex between men because of the stigma associated with such activities, ${ }^{2}$ it is possible that similar under-reporting of same-sex activities (solicitations from men and sexual activities with the solicitors) occurred in this study. Thus the findings of this study should be interpreted with this limitation in mind.

An additional limitation involves the time frames that were used for the alcohol and drug dependence measures. Both measured the previous year or 12 months. However, the question regarding sexual solicitation was phrased in terms of the solicitation having occurred during the time that the individual had been a day laborer in California. Thus we have no way of knowing the extent to which an individual's alcohol- or drug-using behaviors coincided exactly with the time that they had been day laborers.

\section{Conclusions}

The results of this study suggest that a significant percent of Latino day laborers at these day laborer sites identified primarily through the Internet are being solicited for sex by other men. Most of the day laborers who were propositioned for sex did not subsequently engage in sexual activities with their solicitors, and the primary motivation for engaging in sex with solicitors was economic. Those who engaged in sex with their solicitors were found to be more likely to screen positive for drug dependence. HIV prevention staff should be aware that drug dependent day laborers may be placing 
themselves at risk for HIV infection through sex with male solicitors and include them in programs designed to lower the risk of infection.

\section{Acknowledgements}

Support for this project was provided by the California HIV / AIDS Research Program (CHRP) of the University of California Office of the President (ID04-DREW-023 and CH05-DREW-616) and the UCLA/Drew/RAND Center for HIV Identification, Prevention and Treatment Services (CHIPTS) sponsored by the National Institute of Mental Health (P30MH-58-107). We also wish to acknowledge the contributions of the research participants.

\section{References}

I. Organista KC, Carrillo H,Ayala G. HIV prevention with Mexican migrants: Review, Critique and Recommendations. J Acq Immun Def Synd 2004:37:S227-S239.

2. Denner J, Organista KC, Dupree JD, Thrush G. Predictors of HIV transmission among migrant and marginally housed Latinos. AIDS Behav 2005;9:20I-2I0.

3. Fernandez MI, Collazo JB, Hernandez N, Bowen GS, Varga LM, Kibort Vila C, et al. Predictors of HIV risk among Hispanic farm workers in South Florida:Women are at higher risk than men. AIDS Behav 2004;8: 165-174. 4. Organista KC, Organista PB. Migrant laborers and AIDS in the United States:A review of the literature. AIDS Educ Prev 1997;9:83-93.
5. Organista KC, Organista PB, Bola JR, Garcia-de Alba GJE, CastilloMoran MA. Predictors of condom use in Mexican migrant laborers. Am J Commun Psychol 2000;28:245-265.

6. Organista KC, Organista PB, Garcia-de Alba GJE, Castillo-Moran MA, Ureta Carrillo LE. Survey of condom-related beliefs, behaviors, and perceived social norms in Mexican migrant laborers. J Commun Health 1997:22:185-198.

7.Valenzuela A,Theodore N, Melendez, E, Gonzalez AL. On the Corner: Day Labor in the United States [monograph on Internet], Chicago: University of Illinois, 2006. [Accessed on November 2007]. Available at http://www. uic.edu/cuppa/uicued.

8. Walter N, Bourgois P, Loinaz HM. Masculinity and undocumented labor migration: injured Latino day laborers in San Francisco. Soc Sci Med 2004;59:1159-1168.

9. Walter N, Bourgois P, Loinaz HM, Schillinger D. Social context of work injury among undocumented day laborers in San Francisco.J Gen Intern Med 2002;17:221-229.

10. Organista KC, Kubo A. Pilot survey of HIV risk and contextual problems and issues in Mexican/Latino migrant day laborers.J Immigrant Health 2005;7:269-28I.

II. Ehrlich SF, Organista KC, Oman D. Migrant Latino day laborers and intentions to test for HIV.AIDS Behav 2007; I 1:743-752.

12. Babor TF, de la Fuente JR, Saunders J, Grant M.AUDIT:The Alcohol Use Disorders Identification Test: Guidelines for use in primary health care. Geneva:World Health Organization, 1992

13. Saunders JB, Aasland OG, Babor TF, de la Fuente JR, Grant M. Development of the Alcohol Use Disorders Screening Identification Test (AUDIT).WHO collaboration project on early detection of persons with harmful alcohol consumption.Addiction 1993;88:79I-804.

14.TCU Data Collection Forms for Correctional Residential Treatment [Internet site]. Forth Worth:Texas Christian University Institute of Behavioral Research [Accesed on March II, 2002]. Available at www.ibr. tcu.edu/pubs/datacoll/listofforms.html

15. Hosmer DW, Lemeshow S.Applied Logistic Regression. New York: John Wiley \& Sons, 1989. 